\title{
Energy Analysis of Berseem (Trifolium alexandrinum L.) Crop under Different Weed Management Practices in Chhattisgarh
}

\author{
Manju Tiwari*, Shrikant Chitale and Nitish Tiwari
}

Indira Gandhi Krishi Vishwavidyalaya, Raipur (C.G.), India

*Corresponding author

\begin{tabular}{|l|}
\hline K e y w o r d s \\
Berseem, \\
Trifolium \\
alexandrinum, \\
Weed Management \\
\hline Article Info \\
\hline $\begin{array}{l}\text { Accepted: } \\
\text { 20 November } 2020 \\
\text { Available Online: } \\
\text { 10 December } 2020\end{array}$ \\
\hline
\end{tabular}

\section{A B S T R A C T}

Energy utilization pattern is the vital characteristic for successful crop production. In the present paper energy analysis of berseem (Trifolium alexandrinum L.) under different weed management practices has been studied at the Indira Gandhi Krishi Vishwavidyalaya (IGKV), Raipur (C.G.). Significantly the highest total dry fodder yield $(6.51$ and $6.01 \mathrm{t} / \mathrm{ha}$ ) was registered with the application of oxyfluorfen 0.25 $\mathrm{kg} / \mathrm{ha}$ as PE over rest of the treatments during the year 2018-19 and 2019-20. It was also found that the PE application of oxyfluorfen $0.25 \mathrm{~kg} / \mathrm{ha}$ could be a very effective in terms of energy output (mean $112680 \mathrm{MJ}$ ) and energy efficiency (8.46 $\mathrm{MJ} / \mathrm{ha} /$ day $)$ and energy productivity $(0.47 \mathrm{~kg} / \mathrm{MJ})$ among the different weed management practices.

\section{Introduction}

Energy conservation and effective utilization of available resources is of major concern for every economic activity. Energy utilization pattern is a key development indicator in any sector in the current scenario. The worldwide energy crisis caused by fuel shortage and high prices of petroleum has adversely affected the world economy. In order to mitigate the hardship, it is necessary to conserve utilize non renewable energy sources wherever possible, failing which; make efficient use of available conventional energy sources.

In the field of agriculture, energy utilization can be seen in all the farm practices including the use of farm equipment, application of irrigation and pesticides, transportation and food processing. Obviously, this entails the farmer to increase power availability to increase the productivity in the farm. Power is mainly required for tillage, irrigation, harvesting and threshing etc. Increase in the productivity requires additional mechanical and as well as electrical power. Thus, energy input is one of the key factors for successful crop production. The production of crops with high yield targets can be accomplished with higher energy inputs to the system.

Energy requirements for crop production system have been witnessing a dramatic diversification in agriculture (Dhaliwal and Kler, 1995). Agricultural intensification requires more energy and energy input pattern 
for crop production depends on economic, technological and social constraints. Commercial and noncommercial energy are available for agricultural operations. Commercial energy inputs arrive on farm in many different forms, e.g. fuel, irrigation water, chemical fertilizer, machinery and pesticides (Khan and Hussain, 2007). Among field crops, legumes require less energy input than cereals and oilseeds.

Berseem is India's most dominant winter season forage crop with a productivity of 60 $110 \mathrm{t} / \mathrm{ha}$ grown under $1.9 \mathrm{~m}$ ha area (Anonymous, 2012). Although, it is not a crop of Chhattisgarh but is gaining popularity among the farmers because it offers high quality, protein-rich green forage $(15-25 \%)$, minerals (11-19\%) and carotene (Sharma and Murdia, 1974). However, Berseem suffers from strong crop weed competition at initial $30-40$ DAS, or at the time up to $1^{\text {st }}$ cutting and resulted in low quality fodder. At later cuttings, the weeds are smothered by heavy branching and faster growth of berseem. Fodder yield and seed yield losses have been estimated to be $23-30 \%$ and $50 \%$, respectively due to weeds (Joshi and Bhilare, 2006; Alfred, 2012).

\section{Materials and Methods}

The experiment was conducted at the IGKV, Raipur (C.G.) during rabi 2018-19 and 201920 to analyse the energy requirements and output of berseem (Trifolium alexandrinum L.) crop under different weed management practices in Chhattisgarh. The experiment was carried out in randomized block design with six treatments replicated thrice. The treatments involved pendimethalin (PE) 1000 $\mathrm{g} / \mathrm{ha}\left(\mathrm{T}_{1}\right)$, pendimethalin (EPoE) at $10 \mathrm{DAS}$ $1000 \mathrm{~g} / \mathrm{ha}\left(\mathrm{T}_{2}\right)$, oxyfluorfen $(\mathrm{PE}) 250 \mathrm{~g} / \mathrm{ha}$ $\left(\mathrm{T}_{3}\right)$, imazethapyr (PoE) $40 \mathrm{~g} / \mathrm{ha}$, just after $1^{\text {st }}$ cutting $\left(\mathrm{T}_{4}\right)$, imazethapyr (PoE) $40 \mathrm{~g} / \mathrm{ha}$ just after last cutting $\left(\mathrm{T}_{5}\right)$ and imazethapyr $(\mathrm{PoE})$ $\mathrm{g} / \mathrm{ha}$, just after $1^{\text {st }}$ and last cutting $\left(\mathrm{T}_{6}\right)$. In case of dry forage yield, highest and lowest value was obtained under the PE application of oxyfluorfen $250 \mathrm{~g} / \mathrm{ha}\left(\mathrm{T}_{3}\right)$ and imazethapyr (PoE) $40 \mathrm{~g} / \mathrm{ha}$, just after last cutting $\left(\mathrm{T}_{5}\right)$, respectively.

Energy values for various input and outputs used in the experimentation are given in Table 1 (Singh and Mittal, 1992). The total energy input for a given crop was calculated by adding the energy requirement for human labour, diesel, herbicides, seed and fertilizers used, in that sequence.

The output: input ratio was worked out by dividing the total energy generated from main product and by- product by the total energy used for raising the crop in an unit area. The energy input and output were computed as Mega Joule (MJ) by using different formulae. The energy efficiency (EE) was worked out as per Dazhong and Pimental (1984).

$$
\mathrm{EE}=\frac{\text { Energy output }(\mathrm{MJ} / \mathrm{ha})}{\text { Energy input }(\mathrm{MJ} / \mathrm{ha})}
$$

Energy output efficiency (MJ/ha/day) and energy productivity were calculated by:

$$
\begin{gathered}
\begin{array}{c}
\text { Energy output } \\
\text { efficiency }
\end{array} \\
\text { Energy productivity }=\frac{\text { Ynergy output }(\mathrm{MJ} / \mathrm{ha})}{\text { Yield }(\mathrm{kg} / \mathrm{ha})} \\
\text { Energy input }(\mathrm{MJ} / \mathrm{ha})
\end{gathered}
$$

\section{Results and Discussion}

\section{Energy input in Berseem production}

Energy inputs for berseem as required in different weed management practices under the study was ranged between 13416.47 to $13692.95 \mathrm{MJ} / \mathrm{ha}$. Irrigation accounted for a major share of energy input (45.9 to $46.9 \%$ ), followed by field preparation (16.1-16.4\%), seed sowing (15.0-15.3\%), fertilizer (14.0- 
$14.3 \%)$ and harvesting (6.5-6.7\%). The energy input through herbicides $(0.38-2.4 \%)$ was minimum. The highest energy input was recorded in both the treatment of pendimethalin $1000 \mathrm{~g} / \mathrm{ha} \mathrm{PE}$ and $\mathrm{EPoE}\left(\mathrm{T}_{1}\right.$ and $\mathrm{T}_{2}$ ). The lowest energy input was required for the treatment of both imazethapyr $40 \mathrm{~g} / \mathrm{ha}$ just after $1^{\text {st }}$ cutting $\left(\mathrm{T}_{4}\right)$ and just after last cutting $\left(\mathrm{T}_{5}\right)$.

Table.1 Equivalents for various sources of energy

\begin{tabular}{|c|c|c|}
\hline Particulars Inputs (MJ) & Units & Equivalent energy MJ \\
\hline Human labour & Man-hour & 1.96 Mittal et al, 1985 \\
\hline Diesel (3.5 lit/hours) & Litre & 56.31 Mittal et al, 1985 \\
\hline Cultivator & $\mathrm{hr}^{-1}$ & 220.00 Mittal et al, 1985 \\
\hline Seeder & $\mathrm{ha}^{-1}$ & 338.83 \\
\hline Berseem (legume) & $\mathrm{kg}$ & 14.7 Mittal et al, 1985 \\
\hline \multicolumn{3}{|l|}{ Chemical fertilizer } \\
\hline $\mathbf{N}$ & $\mathrm{Kg}$ & 60.60 Mittal et al, 1985 \\
\hline $\mathbf{P}_{2} \mathbf{O}_{5}$ & $\mathrm{Kg}$ & 11.10 Mittal et al, 1985 \\
\hline $\mathrm{K}_{2} \mathrm{O}$ & $\mathrm{Kg}$ & 6.70 Mittal et al, 1985 \\
\hline \multicolumn{3}{|c|}{ Irrigation Each $7.5 \mathrm{~cm}$ Irrigation requires $10 \mathrm{hr} / \mathrm{ha}$ and Irrigation pump is of $15 \mathrm{hp}$} \\
\hline (i) Man & Man-hour & 1.96 \\
\hline (ii) Electricity & KWh & 11.93/hours \\
\hline (iii) Submersible pump & HP & $68.4 / \mathrm{hp}$ \\
\hline Herbicide & $\mathrm{kg}$ a.i & 288 \\
\hline
\end{tabular}

Table.2 Calculation of input energy for berseem crop under different weed management practices in Chhattisgarh

\begin{tabular}{|c|c|c|}
\hline Particulars & Unit required & Total energy MJ \\
\hline Field preparation tractor & per ha & \\
\hline 2 Ploughing +1 planking & 5 hours & 1100.00 \\
\hline Diesel consumption & $3.5 \mathrm{lit} / \mathrm{ha}$ & 985.25 \\
\hline \multirow[t]{2}{*}{ Driver } & 5 hours & 98.00 \\
\hline & Sub total & 2177.25 \\
\hline \multicolumn{3}{|l|}{ Seed and sowing } \\
\hline Berseem (legume) & $25 \mathrm{~kg}$ & 367.50 \\
\hline Seed drill & 3 hours & 1016.49 \\
\hline Diesel consumption & $3.5 \mathrm{lit} / \mathrm{ha}$ & 591.15 \\
\hline \multirow[t]{2}{*}{ Driver } & 3 hours & 8.55 \\
\hline & Sub total & 2032.2 \\
\hline \multicolumn{3}{|l|}{ Fertilizer } \\
\hline Nitrogen 20 kg/ha & $60.60 / \mathrm{kg}$ & 1212 \\
\hline$P_{2} O_{5} 50 \mathrm{~kg} / \mathrm{ha}$ & 11.10 & 555 \\
\hline \multirow[t]{2}{*}{$\mathrm{K}_{2} \mathrm{O} 20 \mathrm{~kg} / \mathrm{ha}$} & 6.7 & 134 \\
\hline & Sub total & 1901.00 \\
\hline \multicolumn{3}{|l|}{ Irrigation } \\
\hline Labour & 2 per irrigation & 98.00 \\
\hline Electricity & 11.93/hours & 119.30 \\
\hline
\end{tabular}




\begin{tabular}{|c|c|c|}
\hline Submer sible pump (15hp) & 68.4/hp (10 hours/irrigation) & 1026.00 \\
\hline & Sub total & 1243.3 \\
\hline (Total 5 irrigation) & & 6216.5 \\
\hline \multicolumn{3}{|l|}{ Forage cutting } \\
\hline \multirow[t]{3}{*}{ Cutting (total 3 cuts) } & 15 labours per cut & 882.00 \\
\hline & Sub total & 882.00 \\
\hline & Grand total & 13208.95 \\
\hline $\begin{array}{l}\text { Treatment Herbicide } \\
\text { application }\end{array}$ & 2 Labours per application & 39.20 \\
\hline 1. Pendimethalin PE & $1 \mathrm{~kg} / \mathrm{ha}$ & 327.20 \\
\hline 2. Pendimethalin (EPoE) & $1 \mathrm{~kg} / \mathrm{ha}$ & 327.20 \\
\hline 3. Oxyfluorfen PE & $0.25 \mathrm{~kg} / \mathrm{ha}$ & 111.20 \\
\hline $\begin{array}{l}\text { 4. Imazethapyr (just after } 1^{\text {st }} \\
\text { cut) }\end{array}$ & $0.04 \mathrm{~kg} / \mathrm{ha}$ & 50.72 \\
\hline $\begin{array}{l}\text { 5. Imazethapyr (just after last } \\
\text { cut) }\end{array}$ & $0.04 \mathrm{~kg} / \mathrm{ha}$ & 50.72 \\
\hline $\begin{array}{l}\text { 6. Imazethapyr (just after } 1^{\text {st }} \\
\text { cut and last cut) }\end{array}$ & $0.04 \mathrm{~kg} / \mathrm{ha}$ & 101.44 \\
\hline
\end{tabular}

Table.3 Energy input requirement for energy output and dry forage yield production of berseem crop under different weed management practices in Chhattisgarh

\section{Treatment}

\begin{tabular}{|c|c|c|c|c|c|c|}
\hline \multirow[t]{3}{*}{ Treatment } & \multicolumn{2}{|c|}{$\begin{array}{l}\text { Total dry forage } \\
\text { yield, t/ha }\end{array}$} & \multicolumn{4}{|c|}{ Energy, MJ/ha } \\
\hline & \multirow[t]{2}{*}{ 2018-19 } & \multirow[t]{2}{*}{ 2019-20 } & \multicolumn{2}{|c|}{ Input } & \multicolumn{2}{|c|}{ Output } \\
\hline & & & Treatment & Total & 2018-19 & 2019-20 \\
\hline Pendimethalin $1 \mathrm{~kg} / \mathrm{ha}(\mathrm{PE})$ & 6.1 & 5.67 & 327 & 135361 & 109800 & 102060 \\
\hline Pendimethalin $1 \mathrm{~kg} / \mathrm{ha}(\mathrm{EPoE})$ at & 6.03 & 5.44 & 327 & 135361 & 108540 & 97920 \\
\hline Oxyfluorfen $0.25 \mathrm{~kg} / \mathrm{ha}$ (PE) & 6.51 & 6.01 & 111 & 133201 & 117180 & 108180 \\
\hline Imazethapyr at $0.04 \mathrm{~kg} / \mathrm{ha}$ after $1 \mathrm{st}$ cutting & 5.25 & 4.52 & 51 & 13260 & 94500 & 81360 \\
\hline Imazethapyr at $0.04 \mathrm{~kg} / \mathrm{ha}$ after last cut & 3.58 & 4.43 & 51 & 13260 & 64440 & 79740 \\
\hline $\begin{array}{l}\text { Imazethapyr at } 0.04 \mathrm{~kg} / \mathrm{ha} \text { after } 1 \text { st cutting fb } \\
\text { Imazethapyr at } 0.04 \mathrm{~kg} / \mathrm{ha} \text { after last cut }\end{array}$ & 5.46 & 5.16 & 1011 & 13310 & 98280 & 92880 \\
\hline
\end{tabular}

Table.4 Energy efficiency, energy output efficiency and energy productivity by berseem crop under different weed management practices in Chhattisgarh

\begin{tabular}{|c|c|c|c|c|c|c|}
\hline \multirow[t]{2}{*}{ Treatment } & \multicolumn{2}{|c|}{$\begin{array}{l}\text { Energy efficiency } \\
\text { MJ/ha/day }\end{array}$} & \multicolumn{2}{|c|}{$\begin{array}{c}\text { Energy output } \\
\text { efficiency } M J / h a / \text { day }\end{array}$} & \multicolumn{2}{|c|}{$\begin{array}{c}\text { Energy productivity } \\
\mathrm{kg} / \mathrm{MJ}\end{array}$} \\
\hline & 2018-19 & 2019-20 & 2018-19 & 2019-20 & 2018-19 & 2019-20 \\
\hline Pendimethalin $1 \mathrm{~kg} / \mathrm{ha}$ (PE) & 8.11 & 7.54 & 954.78 & 887.48 & 0.45 & 0.42 \\
\hline Pendimethalin $1 \mathrm{~kg} / \mathrm{ha}(\mathrm{EPoE})$ at (10 DAS) & 8.02 & 7.23 & 943.83 & 851.48 & 0.45 & 0.40 \\
\hline Oxyfluorfen $0.25 \mathrm{~kg} / \mathrm{ha}(\mathrm{PE})$ & 8.80 & 8.12 & 1018.96 & 940.70 & 0.49 & 0.45 \\
\hline Imazethapyr at $0.04 \mathrm{~kg} / \mathrm{ha}$ after 1 st cutting & 7.13 & 6.14 & 821.74 & 707.48 & 0.40 & 0.34 \\
\hline Imazethapyr at $0.04 \mathrm{~kg} / \mathrm{ha}$ after last cut & 4.86 & 6.01 & 560.35 & 693.39 & 0.27 & 0.33 \\
\hline $\begin{array}{l}\text { Imazethapyr at } 0.04 \mathrm{~kg} / \mathrm{ha} \text { after } 1 \mathrm{st} \text { cutting } \\
\text { fb Imazethapyr at } 0.04 \mathrm{~kg} / \mathrm{ha} \text { after last cut }\end{array}$ & 7.38 & 6.98 & 854.61 & 807.65 & 0.41 & 0.39 \\
\hline
\end{tabular}


Productivity of berseem crop under different weed management practices

In case of dry forage yield, highest (mean $6.26 \mathrm{t} / \mathrm{ha}$ ) and lowest (mean $4.01 \mathrm{t} / \mathrm{ha}$ ) value was obtained under the PE application of oxyfluorfen $250 \mathrm{~g} / \mathrm{ha}$ and imazethapyr (PoE) $40 \mathrm{~g} / \mathrm{ha}$ just after last cutting $\left(\mathrm{T}_{5}\right)$, respectively during both the year. This is due to pre emergence application of herbicides providing weed free condition offered a favorable environment to crops from weeds for light nutrients and moisture. Which results in increased crop growth and thus increase in green forage yield hence, increased dry forage yield.

\section{Energy output of berseem crop under different weed management practices}

Total energy output was computed from forage dry yield of different weed management practices and it ranged from 64440 to $117180 \mathrm{MJ} / \mathrm{ha}$ as per two years production (Table 2). The mean of 2 years revealed that the highest total energy output was obtained from application of oxyfluorfen (PE) $250 \mathrm{~g} / \mathrm{ha}$ followed by the application of pendimethalin (PE) $1000 \mathrm{~g} / \mathrm{ha}$. The lowest energy output was obtained from imazethapyr (PoE) $40 \mathrm{~g} / \mathrm{ha}$, just after last cutting.

\section{Energy-output efficiency and energy productivity}

It was observed that PE application of oxyfluorfen $250 \mathrm{~g} / \mathrm{ha}$ resulted in the highest energy output efficiency (1019 \& 941 MJ/ ha/day), for both the year. However, imazethapyr (PoE) $40 \mathrm{~g} / \mathrm{ha}$, just after last cutting, was less efficient in energy output efficiency $(560 \quad \& \quad 693 \quad \mathrm{MJ} / \mathrm{ha} /$ day $)$, as compared to other weed management practices. Maximum energy productivity was obtained in oxyfluorfen $250 \mathrm{~g} / \mathrm{ha}$ might be due to its higher total dry forage yield (6.51 and $6.01 \mathrm{t} / \mathrm{ha}$ ).
Based on this study, it can be concluded that the oxyfluorfen $250 \mathrm{~g} / \mathrm{ha}\left(\mathrm{T}_{3}\right)$ which may be competent to produce more forage yield, profit per unit cost of cultivation and energy productivity under different weed management practices in Chhattisgarh.

Based on the experiments conducted as detailed above, it is observed that $\mathrm{PE}$ application of oxyfluorfen $250 \mathrm{~g} / \mathrm{ha}$ produced the highest energy output efficiency (1019 \& $941 \mathrm{MJ} / \mathrm{ha} /$ day), for both the year. However, application of imazethapyr (PoE) $40 \mathrm{~g} / \mathrm{ha}$, just after last cutting was found to be less efficient in energy output efficiency (560 \& 693 $\mathrm{MJ} / \mathrm{ha} /$ day) as compared to other weed management practices. It was further noticed that the maximum energy productivity obtained for oxyfluorfen $250 \mathrm{~g} / \mathrm{ha}$ might be due to its higher total dry forage yield (6.51 and $6.01 \mathrm{t} / \mathrm{ha}$ ). On the basis of this study, it is concluded that the oxyfluorfen $250 \mathrm{~g} / \mathrm{ha}$ may be a competent weed control option to produce more forage yield and energy productivity under different weed management practices in Chhattisgarh.

\section{References}

Alfred, S. 2012. Evaluation of herbicides for weed management in berseem (Trifolium alexandrinum L.) M.Sc. Thesis, Govind Ballabh Pant University of Agriculture and Technology, Pantnagar, p. 98

Anonymous. 2012 Handbook of Agriculture published by Indian Council of Agricultural Research, New Delhi, P. 1346.

Chaudhary, V.P., Gangwar, B., Pandey, D.k., Gangwar, K.S. 2009. Energy auditing of diversified Paddy-wheat cropping systems in Indo-Genetic plains. Energy 34, 1091-1096.

Dazhong, W. and Pimental, D. 1984. Energy flow through an organic farming 
ecosystem in China. Agriculture Ecosystem Environment 11: 145-60.

Dhaliwal, G.S. and Kler, D.S. 1995. Principles of Agricultural Ecology, pp. 325. Himalaya Publishing House, Bombay.

Joshi, Y. P. and Bhilare, R. L. 2006. Weed management in berseem (Trifolium alexandrinum L.). Pantnagar Journal of Research, 4(1): 14-17

Khan, M.A. and Hussain, S.M.A. 2007. Study on energy input output, and energy-use efficiency of major jute based cropping pattern. Bangladesh journal of Scientific and Industrial Research 42 (2): 195-02.

Kuswardhani, N., Soni, P., Shivakoti, G.P., 2013. Comparative energy input-output and financial analyses of green house and open field vegetable production in West java, Indonesia. Energy 53, 83-92.

Mittal, V.K., Mittal, J.P. and Dhawan, K.C. 1985. Research Digest on Energy
Requirements in Agricultural sector. Coordinating cell, AICRP on energy requirements in Agricultural sector. Punjab Agricultural University, Ludhiana.

Nassiri, S.M., Singh, S., 2009. Study on energy use efficiency for paddy crop using data envelopment analysis (DEA) technique. Appl. Energy 86. 1320-1325.

Singh, S., and Mittal, J.P. 1992. Energy in Production Agriculture, pp. 143. Mittal Publications, New Delhi.

Soni. P., Taewichit, C., Salokhe, V.M., 2013. Energy consumption and $\mathrm{CO}_{2}$ emissions in rain-fed agricultural production systems of Northeast Thailand. Agric. Syst. 116. 25-36.

Sharma, V.V. and Murdia, P.C. 1974. Utilization of berseem hay by ruminants. Journal of Agricultural Sciences, 83: 289-293.

\section{How to cite this article:}

Manju Tiwari, Shrikant Chitale and Nitish Tiwari. 2020. Energy Analysis of Berseem (Trifolium alexandrinum L.) Crop under Different Weed Management Practices in Chhattisgarh. Int.J.Curr.Microbiol.App.Sci. 9(12): 3563-3568.

doi: https://doi.org/10.20546/ijcmas.2020.912.423 